\title{
Towards a More Holistic Approach to Pollination
}

\author{
Liliana Bravo-Monroy G* \\ Alumnus of Centre for Agri-Environmental Research, Reading University, UK
}

Submission: February 02, 2017; Published: February 09, 2017

"Corresponding author: Liliana Bravo-Monroy G, Alumnus of Centre for Agri-Environmental Research, School of Agriculture, Policy and Development, Reading University, UK, Email: libravo@yahoo.com

\begin{abstract}
Pollination plays a key role in food production, biodiversity conservation and maintenance of ecosystem integrity. The objective of this article is to suggest pollinator-friendly actions by addressing the following question: what actions at local scale might contribute towards a more effective implementation of management options? Using as starting point the Intergovernmental Platform on Biodiversity and Ecosystem Services (IPBES) thematic assessment on pollinators, pollination and food production, two main actions are proposed: the dissemination of information, and measurement of impact through potential performance indicators. Each one has the purpose to meet two key aims, communication and capacitybuilding respectively, which is possible to extrapolate to other ecosystem services. Thus local information can complement and explain data from larger scale, in search of sustainable, socially equitable, and ecologically successful management.
\end{abstract}

Keywords: Pollination; Outreach; Monitoring indicators; Society's relationships with nature

\section{Introduction}

Pollination plays a key role in food production, biodiversity conservation and maintenance of ecosystem integrity Potts et al. [1]. Globally nearly $90 \%$ of wild flowering plant species depend on animal pollination Ollerton, et al. [2]. More than $75 \%$ of leading global crop types benefit from animal pollination in production, yield and quality Klein, et al. [3]. Some fruit crops are completely dependent on pollinators, and for others pollination results in better quality fruit. For instance, apple yields are between $40 \%$ and $90 \%$ lower without pollinators, depending on the variety Blitzer, et al. [4]; Garratt, et al. [5]; without pollination watermelon yields drop by $90 \%$ Winfree, et al. [6]. Insects, particularly bees, are the primary pollinators of most agricultural crops and wild plants. Pollination services in turn depend on both domesticated and wild pollinator populations, both of which are affected by environmental changes such as habitat destruction, fragmentation and degradation, the use of insecticides and climate change Potts et al. [7].

The objective of this article is to suggest two actions using as starting point the IPBES thematic assessment on pollinators, pollination and food production; by addressing the following question: what actions at local scale might contribute towards a more effective implementation of management options? The text begins with a brief introduction of the importance of pollinators. Then the core of the approach is to illustrate two main actions: the dissemination of information, and measurement of impact through potential performance indicators. For a better understanding of the implementation of the assessment, it is relevant to examine these topics.

\section{Importance of Pollinators}

Pollinators play a key role in regulating ecosystem services supporting food production, habitats and natural resources. In particular, plants depend on pollination since need pollinators to transfer pollen for successful sexual reproduction. These plants are crucial in the functioning of ecosystems due to provide food, form habitats and provide a wide range of other resources for many species. Pollinators are a source of multiple benefits to people, beyond food provisioning, contributing directly to medicines, bio fuels (e.g. canola and palm oil), fibres (e.g., cotton and linen) construction materials (timbers), musical instruments, arts and crafts, recreational activities and as sources of inspiration for art, music, literature, religion, traditions, technology and education. In the context of food, the production volume of pollinator-dependent crops has increased threefold over the last five decades, making us more dependent on pollination. These crops include fruits and vegetables and are essential for human diets and nutrition, since they provide us with vitamins and minerals. Around 5-8\% of current global crop production is directly ascribed to animal pollination, which equates to somewhere between 235 and 577 billion American dollars worldwide IPBES [8]. 


\section{Dissemination of Information by Pollination Outreach Activities}

With the aim of disseminating selected information of the IPBES pollination assessment as well as building or increasing public awareness of pollinator diversity, this section proposes three practical workshops.

\section{People's interpretation of pollination}

It is suggested to give participants the task of representing a well-known flower/pollinator/plant-pollinator interaction on paper. Once people's interpretation of pollination has been described, it will be analysed potential pollinators (e.g., generalists, specialists) and their surrounding landscape/agro-ecosystem, based on a background of images related to morphology and colour of common/conspicuous flowers (orchids, sunflowers, etc.). Two ways of discussion are proposed: firstly, from particular (plantpollinator interaction) to general (landscape context) perspective and vice versa; secondly, analysing co-evolution of plant and pollinators.

\section{Pollination Story}

Based on the IPBES assessment, short pollination stories are given to groups of participants with the aim of capturing the story in collaborative drawings. Stories can include multiple sociocultural values of pollinators on different locations of the world; and several examples of how local knowledge fosters pollinators and pollination; for instance, Petalangan indigenous people (Indonesia) view bees as a symbol of health and prosperity and the trees, where the bees nest, as a symbol of the universe; similarly, within the U'wa mythology (Colombia), bees are appreciated as beings that made possible the origins of life and natural light in the universe. Then, groups aren't allowed to communicate what the story is about. Once the drawings are done, they hold the poster up to show the other groups, who would guess what the original article was about.

\section{Planting a pollinator garden}

A real opportunity for action based on training and creative learning that provides information and hands-on practice (e.g., educational material, booklets) with pollinator habitat enhancement techniques for the broader public (e.g., BCT 2017).

\section{Assessment of Impact - Performance Indicators}

Performance indicators might allow identifying changes and trends over time so managers can assess whether implemented activities are achieving pollination goals. In the context of the Convention on Biological Diversity [9,10], this section proposes a sample of potential performance indicators relevant to two Aichi Biodiversity targets aimed at monitoring the effectiveness of local actions related to pollinator-friendly management. In particular, the first Aichi target concerns awareness raising of the values of biodiversity and the steps people can take to conserve and use it sustainably. In line with this, a group of indicators towards this target could be:

\section{Monitoring participation and community involvement}

a. Changes in understanding/ acknowledgment of pollinator-friendly management by farmers and other actors;

b. Extent to which community feels involved in management at different levels (e.g., decision-making, consultation, etc.);

c. Extent to which community understands and agrees with management approaches;

d. Change in level of knowledge exchange among scientists and local stakeholders about pollinator conservation;

e. Number of awareness programs/activities undertaken and/or number of educative institutions visited.

f. Status of monitoring information management system;

The role of community-based monitoring is crucial at local scale since can inform decision-making and policy at local, regional and national scales. Indicators can be quantitative or qualitative variables. As a manner of motivating public engagement with biodiversity, those indicators should integrate local knowledge and multiple socio-cultural values (e.g., an agro ecosystem that generates or communicates a symbolic meaning as well as other essential services). Thus the involvement of major stakeholders in the development of a broadly accepted monitoring system is facilitated besides the role of policy makers and scientists.

On the other side according to the target 14, "ecosystems that provide essential services, including services related to water, and contribute to health, livelihoods and well-being, are restored and safeguarded, taking into account the needs of women, indigenous and local communities, and the poor and vulnerable". Consistent with the target, the following category of indicators acting locally could be:

\section{Monitoring management capacity, institutional and socio-economic factors}

a. Change in number or percent of farmers implementing pollinator-friendly practices;

b. Changes in levels of use toward or away from pollinatorfriendly use;

c. Change in institutional arrangements and/or management structure;

d. Existence of pollination agreements and agreed procedures for conflict resolution on management issues;

e. Change in appreciation of pollinators on farms/land.

f. Increase in cash or in-kind benefits returned to community as a result of pollinator-friendly practices;

In addition to changes by using red list indexes, coverage by protected areas and food insecurity experiences, monitoring institutional and governance factors is very important at local scale. For instance, how a particular governance scheme (formal and/or 
informal) contribute to the exercise of authority, management and access to natural resources through institutions, policies, traditions, cultures, and societal norms. Thus ensuring (or not) better living conditions for the human wellbeing and biodiversity. Societies, in this regard, are shaped by powerful social norms and institutions such as gender and age which play a significant role in the livelihood strategies of many households Ellis [11].

To summarise, two actions have been suggested at local scale that might contribute towards a more effective implementation of pollinator-friendly management: dissemination of information and monitoring by performance indicators. Each one has the purpose to meet two key objectives, communication and capacity-building respectively, which is possible to extrapolate to other ecosystem services. It is therefore vital to firstly determine the success of results at local scale considering findings of local observations of society's relationships with nature and then understanding what people are doing, why and with what effect on landscapes. Nourishing current environmental debates with a plethora of several socio-cultural values including different ways in which nature is understood by arts, might contributing to help break down barriers, public engagement and create spaces for conflict resolution. In such a situation, local information can complement and explain remote data on how a region changes over longer periods of time and on larger geographical areas, in search of sustainable, socially equitable, and ecologically successful management $[12,13]$.

\section{References}

1. Potts SG, Imperatriz-Fonseca VL, Ngo HT, Biesmeijer JC, Breeze TD, et al. ecretariat of the Intergovernmental Science-Policy Platform on Biodiversity and Ecosystem Services, Bonn, Germany, p. 36.
2. Ollerton J, Winfree R, Tarrant S (2011) How many flowering plants are pollinated by animals? Oikos 120(3): 321-326.

3. Klein AM, Vaissiere BE, Cane JH, Steffan-Dewenter I, Cunningham SA, et al. (2007) Importance of pollinators in changing landscapes for world crops. Proceedings of the Royal Society of London B274: 303-313.

4. Blitzer EJ, Gibbs J, Park MG, Danforth BN (2016) Pollination services for apple are dependent on diverse wild bee communities. Agriculture Ecosystems \& Environment 221: 1-7.

5. Garratt MP, Breeze TD, Caston DJ, Truslove CL, Lappage MG, et al. (2016) Apple pollination: Demand depends on cultivar and supply depends on pollinator identity. Plos One.

6. Winfree R, Williams NM, Gaines H, Ascher JS, Kremen C (2008) Wild bee pollinators provide the majority of crop visitation across land-use gradients in New Jersey and Pennsylvania, USA. Journal of Applied Ecology 45(3): 793-802.

7. Potts SG, Biesmeijer JC, Kremen C, Neumann P, Schweiger O, et al (2010) Global pollinator declines: trends, impacts and drivers. Trends in Ecology and Evolution 25(6): 345-353.

8. IPBES (2016) Summary for policymakers of the assessment report of the Intergovernmental Science-Policy Platform on Biodiversity and Ecosystem Services on pollinators, pollination and food production.

9. CBD (2017a) Aichi Biodiversity targets.

10. https://www.cbd.int/doc/strategic-plan/strategic-plan-indicators-en. pdf

11. Ellis F (2000) Rural livelihoods and diversity in developing countries. Oxford University Press, India, pp. 273.

12. http://bumblebeeconservation.org/get-involved/gardening-for-bees/

13. Potts SG, Woodcock BA, Roberts SPM, Tscheulin T, Pilgrim ES, et al (2009) Enhancing pollinator biodiversity in intensive grasslands. Journal of Applied Ecology 46(2): 369-379.

\section{Your next submission with Juniper Publishers will reach you the below assets}

- Quality Editorial service

- Swift Peer Review

- Reprints availability

- E-prints Service

- Manuscript Podcast for convenient understanding

- Global attainment for your research

- Manuscript accessibility in different formats

( Pdf, E-pub, Full Text, Audio)

- Unceasing customer service

Track the below URL for one-step submission

https://juniperpublishers.com/online-submission.php 